\begin{tabular}{c} 
Volume and Issues Obtainable at Center for Sustainability Research and Consultancy \\
Journal of Accounting and Finance in Emerging Economies \\
ISSN: $2519-0318$ ISSN (E) 2518-8488 \\
Volume 6: Issue 4 December 2020 \\
¿SRட \\
Journal homepage: $\underline{\text { www.publishing.globalcsrc.org/jafee }}$ \\
\hline
\end{tabular}

\title{
An Empirical Implementation of Markowitz Modern Portfolio Theory on Indonesia Sharia Equity Fund: A Case of Bahana Icon Syariah Mutual Fund
}

\author{
${ }^{1}$ Raka Nuralif Verdiyanto, ${ }^{2}$ Oktofa Yudha Sudrajad, ${ }^{3}$ Faradilla Meyriska \\ ${ }^{1 \& 2}$ School of Business and Management, Institut Teknologi Bandung, Indonesia \\ raka_verdiyanto@sbm-itb.ac.id, oktofa@sbm-itb.ac.id
}

${ }^{3}$ PT Bahana TCW Investment Management, Jakarta, Indonesia faradilla.meyriska@bahana.co.id

\begin{tabular}{l} 
ARTICLE DETAILS \\
\hline History \\
Revised format: November \\
2020 \\
Available Online: December \\
2020
\end{tabular}

\section{Keywords}

Sharia Equity Fund, Markowitz Modern Portfolio

Theory, Risk-adjusted

Return, Sharpe Ratio, Active

Investment Strategy

\section{JEL Classification}

M4, M40

\begin{abstract}
Bahana Icon Syariah, one of Bahana TCW's mutual fund products, is less preferred by investors due to historical poor performance over the last five years compared to the reference index of Indonesia Sharia Stock Index (ISSI). Therefore, this study will evaluate and determine the optimal portfolio using the Markowitz's Modern Portfolio Theory in four different market conditions - overall in the last five years, sideways, bullish, and bearish - with two variables, active and semi-active investment strategy. Data input refers to stocks that have always been recorded at least 80\% in the Jakarta Islamic Index 30 (JII 30) and Jakarta Islamic Index 70 (JII 70) from October 2015 to October 2020. The findings reveal that active investment strategy is always superior to the semi-active under any form of market conditions. The results showed that there were 8 stocks worthy of being included in the portfolio, 4 stocks worthy of consideration, and 9 stocks worthy of being removed from the portfolio. The results are expected to be used and developed as one of the company's tools to obtain optimal portfolio returns.
\end{abstract}

\section{OPEN ACCESS}

(C) 2020 The authors, under a Creative Commons AttributionNonCommercial-ShareAlike 4.0

Corresponding author's email address: raka_verdiyanto@sbm-itb.ac.id

Recommended citation: Verdiyanto, R. N., Sudrajad, O. Y. \& Meyriska, F. (2020). An Empirical Implementation of Markowitz Modern Portfolio Theory on Indonesia Sharia Equity Fund: A Case of Bahana Icon Syariah Mutual Fund. Journal of Accounting and Finance in Emerging Economies, 6 (4) 1159-1172

\section{Introduction}

According to World Economic Outlook: A Long and Difficult Ascent published by International Monetary Fund (IMF) in October 2020, the IMF has changed Indonesia's economic growth forecast from 0.5 percent in June 2020 to shrink by 1.5 percent by the end of 2020. The downward revision for Indonesia is attributable to the ongoing spread of the pandemic and the adverse impact on severely affected sectors. Although social distancing will continue through 2021, the economy is expected to rebound as vaccine coverage has improved and government fiscal spending has been expanded. The rise in commodity prices and accommodative fiscal and monetary policies would help lift the economy. In conclusion, the IMF forecast that the Indonesian economy will boost and expand by approximately 6.1 percent in 2021 . 
The correlation between economic growth and the stock market is a recurring question amongst investors and analysts. While several researchers believe that both numbers theoretically should be the same, others think that there is no connection at all. Park (1997) conducted research on the correlation between real rate of stock return (price appreciation and dividends) on S\&P 500 Index stocks and five real macroeconomic variables, including annualized growth rates of nonfarm payrolls (employment), Gross Domestic Product (GDP), private investment, industrial production, and retail sales. The data included weekly, quarterly and annual data covering the 40 years between 1956 and 1995. Stock returns were found to be most negatively with employment growth and most positively to growth in GDP. With strong statistical and economic significance, GDP has positive coefficients. In one of the models, when GDP rises by 1 percentage point, stock return rises by 3.38 percentage points. Both statistical and economic significance are relatively poor for the other three variables. In order to analyze the effect of the shift in investment and the rate of GDP growth on Amman Stock Exchange (ASE) index for the period 1990 2009, Al-Abedallat and Al Shabib (2012) use statistical analysis and multiple regression. The research concluded that market movements on the ASE were affected by the movements of these two macroeconomic factors.

The cross-sectional correlation between the compounded actual return on equity and the compounded growth rate of real per capital GDP for 19 developed countries over the 112-year period beginning in 1900 and ending in 2011 is -0.39 (Dimson, Marsh, \& Staunton, 2012). This negative correlation implies that investors were actually better off investing in companies in countries that have ended up experiencing lower economic growth per capital economic growth, rather than investing in countries with higher average per capita growth rates. Not only developed countries, but even emerging countries have witnessed this negative result. For 15 emerging markets over the 24-year period from 1988 to 2011 including BRIC countries of Brazil, Russia, India, and China - the correlation is strikingly close to -0.41 (Ritter, 2012).

Setiawan (2020) reveals that the GDP and Indonesia Stock Exchange (IDX) Composite are significantly positive. In this analysis, the IDX Composite was taken from the closing index at the end of each year from 1999 to 2019 on the last trading day. The GDP constant price data for the same period was taken from the official website of the World Bank. To evaluate the effect of GDP on the stock market, multiple regressions were applied. The results show that every $1 \%$ rise in GDP will bring positive effect to Indonesia Stock Exchange (IDX) Composite as $1.03 \%$. This is somewhat conflicted with the findings from Ritter (2012) that mentioned if GDP affects the stock market negatively. The findings of the experiments were somewhat contradictory, depending on the geographical areas and the time framework of the research.

According to Indonesia Central Securities Depository as of July 2020, the most significant growth in the number of investors lies in mutual fund instruments by $30.50 \%$, followed by investors in state securities $(21.09 \%)$ and stock investors $(15.88 \%)$. A wider distribution channel is driving the growth of mutual fund investors, especially through the use of information technology, marketing campaigns, and more efficient in account opening. In general, mutual funds can be divided into money market, fixed income, equity, and a mixture of the three investment instruments. Money market funds invest only in debt securities with a maturity of less than one year, fixed income funds invest at least $80 \%$ of their investments in the form of debt securities, equity funds invest at least $80 \%$ of their assets in the form of stocks, while balanced funds invest in a combination of money markets, debt and equity instruments. The equity funds were the most related category of mutual funds to the growth of the Indonesia Stock Exchange (IDX) Composite out of the four classifications of mutual funds.

The comparison of the net asset value (NAV) of sharia and conventional mutual funds over the last 10 years is shown in Figure 1.1. As of October 2020, the NAV of the conventional mutual funds was much higher (IDR 458 Trillion) than the NAV of sharia mutual funds (IDR 72 Trillion). However, in the perspective of NAV performance as measured by the compounded annual growth rate (CAGR), the NAV 
growth in sharia mutual funds is much higher at $29.9 \%$ per annum compared to $12.3 \%$ in conventional mutual funds. The growth in the number of mutual fund investors and NAV in sharia mutual funds, supported by the prospect of Indonesia's growth in 2021 is a golden opportunity for the asset management industry to offer their mutual fund products to investors.

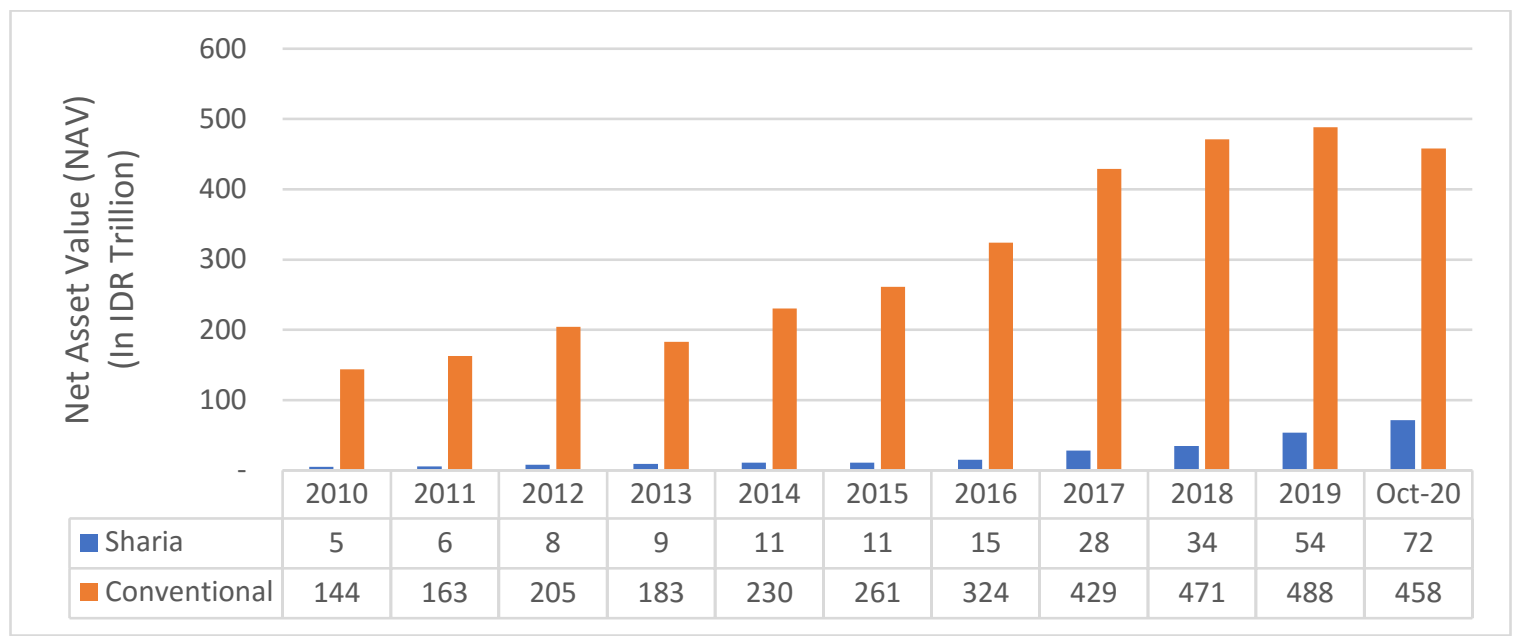

Note: CAGR Sharia by $29.9 \%$, CAGR Conventional by $12.3 \%$

Source: Indonesia Financial Service Authority (as of October 2020)

Figure 1.1 The comparison of sharia's NAV and conventional mutual funds

Bahana Icon Syariah, one of Bahana TCW's sharia mutual fund products, is less preferred by investors due to historical poor performance over the last five years (Figure 1.2) compared to the reference index of Indonesia Sharia Stock Index (ISSI). The performance is not in line with the objective of actively managed investment funds to beat the benchmark index and obtain an optimal rate of return in the long-term through the majority investments in sharia stocks securities. It will be difficult for the company to promote Bahana Icon Syariah to potential investors. Therefore, this study will evaluate and determine the optimal portfolio for Bahana Icon Syariah using the modern portfolio theory concept developed by Harry Markowitz.

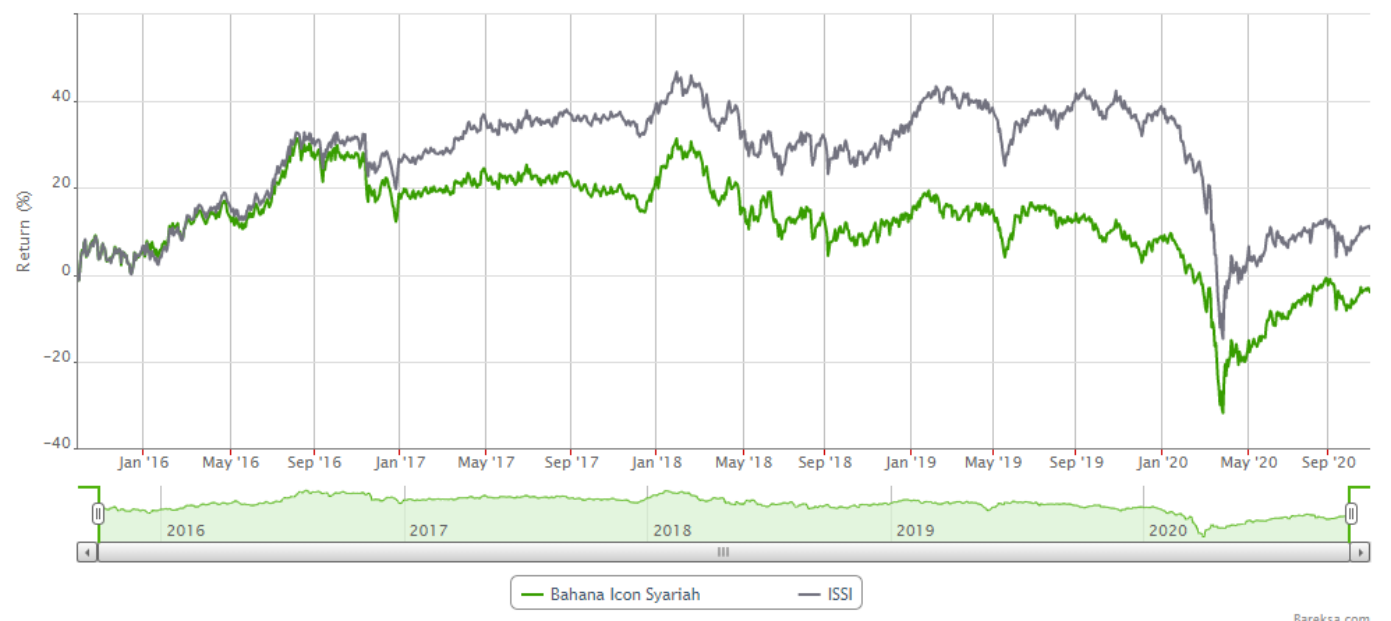

Source: PT Bareksa Portal Investasi

Figure 1.2 Bahana Icon Syariah performance

\section{Literature Review}

An American financial economist, Markowitz (1952) developed the modern portfolio theory in the article of Portfolio Selection, then later refined by Markowitz (1959). Generally, investors have two objectives, namely maximizing the expected value of returns and minimizing the risk. Markowitz explained that to minimize risk and still get a sizeable return, it can be done by forming a diversification of portfolio. On the basis of a return-risk (mean-variance) bi-criterion context and expected utility maximization, 
Markowitz introduced a portfolio optimization method. Markowitz attempted to fulfill this by creating two distinct approaches: by maintaining variance (risk) as constant and optimizing the expected return or keeping return as constant and minimizing variance to select the optimal portfolio. In fact, this contributed to the development of the modern portfolio theory (MPT). The concept introduced by MPT is still at the core of many modern approaches in asset allocation, risk management, and investment analysis.

The Markowitz model believes that investors are avers to risk. This implies that investors would choose the less risky one over two assets that deliver the same expected return. Thus, only when compensated by higher expected returns, investors will take on increased risk. The definition of Markowitz's model is based on several assumptions relating to the behavior of investors and financial markets (Lee, Finnerty, \& Chen, 2010) :

1. For a given holding period, investors should predict the probability of the distribution of future returns.

2. In the sense of declining marginal utility of wealth, investors have single-period utility functions in which they optimize utility.

3. Investors use uncertainty in terms of potential return values to quantify risk.

4. Investors really think of the means and variance in the returns of their investments over a given period.

5. The first two moments of the probability distribution of returns are determined by the expected return and risk as used by investors-expected value and variance.

6. It is desirable to return, it is important to avoid risk.

7. There are frictionless capital markets.

\subsection{Rate of Return}

Rate of return is the amount of profit generated by an investment, calculated as a proportion of the amount of the initial investment. Investors depend on the rate of return of various investment options when determining where to invest their capital. The formula of rate of return is equivalent to formula (1) where $P_{t}$ is the adjusted closing price at time $t$.

$$
r_{t}=\frac{P_{t}-P_{t-1}}{P_{t-1}}
$$

The adjusted closing price is a measurement adjustment made to the closing price of a stock after accounting for certain corporate actions, such as dividends, stock splits, and right offerings. These adjustments allow investors to acquire an accurate record of the results of the stock.

\subsection{Expected Return}

The expected returns from an investment are calculated based on recent or historical performance. Due to the volatility of the future, the expected returns will differ considerably from historical returns. Therefore, no guarantee of the calculated expected returns is issued. The expected return $\left(\mu_{\mathrm{i}}\right)$ on asset $i$ where $i=1$, $\ldots, \mathrm{n}$ is determined by formula (2) where $r_{t}^{i}$ is the return on asset $i$ between periods $\mathrm{t}$ and $\mathrm{t}-1$ and $m$ reflects the number of periods.

$$
\mu_{i}=E\left(r^{i}\right)=\frac{\sum_{t=1}^{m} r_{t}^{i}}{m}
$$

\subsection{Variance and Standard Deviation}

Variance $\left(\sigma_{i}^{2}\right)$ corresponds to a mathematical calculation in a data collection of the spread between numbers. In fact, variance calculates the deviation from the mean of each number in the set and hence from every other number in the set. The variance on asset $i$ is determined using the equation (3):

$$
\sigma_{i}^{2}=\operatorname{Var}\left(r^{i}\right)=\frac{\sum_{t=1}^{m}\left(r_{t}^{i}-\mu_{i}\right)^{2}}{m-1}
$$

The standard deviation calculates a dataset's dispersion in comparison to its mean and is measured as the variance's square root. All uncertainty is determined by the standard deviation as risk. The higher risk 
between each price and the mean is shown by a high standard deviation. The formula (4) of standard deviation is as follows:

$$
\sigma_{i}=\sqrt{\sigma_{i}^{2}}=\sqrt{\frac{\sum_{t=1}^{m}\left(r_{t}^{i}-\mu_{i}\right)^{2}}{m-1}}
$$

\subsection{Covariance}

The directional relation between returns on two assets is measured by covariance which was determined by multiplying the association between the two variables by each variable's standard deviation. A positive covariance indicates that returns from investments move together, while a negative covariance implies that they move inversely. In the return covariance matrix $\left(\Omega_{\mathrm{n} n \mathrm{n}}\right)$, dimensions of covariance are ordered. In its principal diagonal and covariance, the matrix (5) includes variances among all pairs of securities:

$$
\begin{gathered}
\Omega_{n \times n}=\left(\begin{array}{cccc}
\sigma_{1}^{2} & \sigma_{12} & \cdots & \sigma_{1 n} \\
\sigma_{21} & \sigma_{2}^{2} & \cdots & \sigma_{2 n} \\
\vdots & \vdots & \ddots & \vdots \\
\sigma_{n 1} & \sigma_{n 2} & \cdots & \sigma_{n}^{2}
\end{array}\right) \\
\sigma_{i j}=\operatorname{Cov}\left(r^{i}, r^{j}\right)=\frac{\sum_{t=1}^{m}\left(r_{t}^{i}-\mu_{i}\right)\left(r_{t}^{j}-\mu_{j}\right)}{m}
\end{gathered}
$$

\subsection{Expected Portfolio Return and Risk}

Provided any number of volatile assets and a set of weights defining how the investment in the portfolio is divided, the general formula of expected return for $n$ assets is equivalent to equation (6) where $n$ is the number of shares, $w_{i}$ is the proportion of the funds invested in security $i, r_{i}$ and $r_{p}$ are the return on security $i$ and portfolio $p$, and the amount of $w_{i}$ should equal to 1 .

$$
E\left(r_{p}\right)=\sum_{i=1}^{n} w_{i} E\left(r_{i}\right)
$$

The variance of the return of a portfolio (formula 7) consists of two elements: the weighted average of individual asset variance and the weighted covariance between individual asset pairs.

$$
\operatorname{Var}\left(r_{p}\right)=\sigma_{p}^{2}=\sum_{i=1}^{n} \sum_{j=1}^{n} w_{i} w_{j} \operatorname{Cov}\left(r_{i}, r_{j}\right)
$$

In terms of the correlation coefficient where $p_{i j}$ is correlation coefficient between the rates of return on security $i\left(r_{i}\right)$ and the rates of return on security $j\left(r_{j}\right)$, covariance can also be represented as formula (8).

$$
\operatorname{Cov}\left(r_{i}, r_{j}\right)=p_{i j} \sigma_{i} \sigma_{j}=\sigma_{i j}
$$

\subsection{Portfolio Efficient Frontier}

The efficient frontier, which is the set of ideal portfolios providing the highest expected return for a certain risk level or the lowest risk for a given expected return level, is represented in Figure 2.1. A minimum variance portfolio (MVP) refers to a well-diversified portfolio composed of individual risky assets that when sold together are hedged, resulting in the lowest possible risk for the expected rate of return. The portfolio that is immediately above it on the upward sloping of the frontier curve dominates every portfolio on the downward sloping portion of the frontier curve since that portfolio has a higher expected return and an equivalent standard deviation (Chen, Chung, Ho, \& Hsu, 2010). The best decision would focus on the ability of the investor to trade off risk against the expected return. 


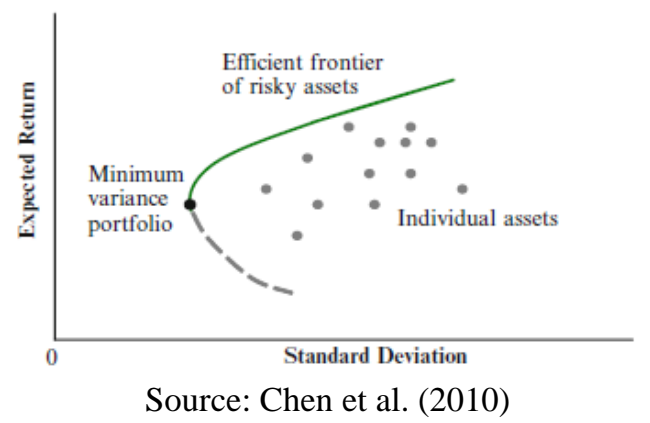

Figure 2.1 The efficient frontier of risky assets and individual assets

\subsection{Sharpe Ratio}

Sharpe (1966) implemented a portfolio performance metric that offers the risk premium per unit of overall risk, determined by the standard deviation of return $\left(\sigma_{p}\right)$. On a portfolio structure, the risk premium $\left(r_{p}\right)$ is the overall portfolio return minus the risk-free rate $\left(r_{f}\right)$. Sharpe ratio $\left(S_{p}\right)$ can be expressed:

$$
S_{p}=\frac{E\left(r_{p}-r_{f}\right)}{\sigma_{p}}
$$

\subsection{Prior Research}

The literature review on the implementation of Markowitz's modern portfolio in several developing countries, including Indonesia, Bulgaria, Malaysia, Thailand, and Vietnam is being reviewed. Research by Yuana, Topowijono and Azizah (2016) aims to find optimal portfolio of stocks that are listed in the Jakarta Islamic Index (JII) in the period of June 2013 to November 2015. There are several stocks which result in negative values based on the measurement of the expected rate of return. These stocks are not included in the next calculation because it is not possible to form an optimal portfolio. The results showed that there were seven stocks included in the optimal composition, including PT AKR Corporindo Tbk (AKRA), PT Astra Agro Lestari Tbk (AALI), PT Indofood CBP Sukses Makmur Tbk (ICBP), PT Kalbe Farma Tbk (KLBF), PT Unilever Indonesia Tbk (UNVR), and PT United Tractors Tbk (UNTR).

A practical analysis of the Markowitz model on the Bulgarian Stock Exchange (BSE) during the period from January 2013 to December 2016 is given by Ivanova and Dospatliev (2017). It was found from the data inputs, which are the weekly closing price of 50 shares exchanged on the BSE, the efficient portfolios created by the Markowitz model performed better than any domestic individual security. Investors are able to achieve optimum return on investment, maximum Sharpe ratio or minimum risk by engaging in optimum portfolios that situated on the efficient frontier. It is the force of diversification of Markowitz by seriously taking into consideration of covariance and asset correlation.

Vo et al. (2019) explores industry-level risk, return and portfolio diversification in four ASEAN member countries for which necessary information is available: Vietnam, Thailand, Malaysia, and Singapore. Market indexes for 10 sectors, covering numerous economic cylces from 2007 to 2016, including 20072009 (crisis), 2010-2012 (post-crisis), and 2013-2016 (normal), are analyzed. To measure extreme risk, Conditional value at risk $(\mathrm{CVaR})$ is used. The risk-return method of Markowitz is utilized to assess the optimum weight of the portfolio sectors. Results from this research suggest the best-performing industry ranges across four countries. In Vietnam and Singapore, health care plays a dominant role. Consumer services are in first place in Thailand and Malaysia. This research offers additional evidence for policymakers to devise effective economic strategies that take advantage of the relative strengths of different industries in their economies.

\section{Research Methodology}

Primary data is the type of data collected directly on a personal level interview with equity analysts, while secondary data is the data that has already been collected through primary sources and made readily available in the forms of previous research, annual reports, and web information from the Indonesia Stock 
Exchange, Indonesia Financial Services Authority, Yahoo Finance, Bloomberg, PT Bahana TCW Investment Management, and PT Bareksa Portal Investasi.

The performance of net asset value (NAV) of the Bahana Icon Syariah was evaluated in several market conditions, including overall condition over the last five years (October 2015 - October 2020), sideways (May - October 2018), bullish (October 2018 - February 2019), and bearish (December 2019 - March 2020). Stock screening analysis refers to:

a. Stocks that have always been recorded at least 80 percent in the Jakarta Islamic Index 30 (JII 30) and Jakarta Islamic Index 70 (JII 70) during the overall research period,

b. Stocks that are listed on the Indonesia Stock Exchange (IDX) for more than 1 year,

c. Stocks that have never had a track record of being suspended for more than one trading day,

d. Non-stocks that have a market value per share of IDR 50,

e. Stock performance shown by Sharpe ratio is positive and / or higher than the ISSI. The risk-free rate refers to the 1-year Bank of Indonesia rate at 5.25\% as of 13 October 2020 (overall), at 7.00\% as of 23 October 2018 (sideways), at $7.25 \%$ as of 21 February 2019 (bullish), and at $5.75 \%$ as of 19 March 2020 (bearish).

The most crucial stage is the transformation of raw data into the concept of modern portfolio theory, invented by Harry Markowitz. In this research, modern portfolio theory was elaborated with active and semi-active investment strategy using Solver tool in Microsoft Excel.

\section{Results and Analysis}

\subsection{Stock Screening Analysis}

Based on the prospectus, Bahana Icon Syariah may invest in this investment instruments:

- Minimum $80 \%$ and maximum $100 \%$ on sharia stocks listed in the Sharia Securities List,

- Minimum 0\% and maximum 20\% in cash equivalents and / or sharia money market instruments which represented by Bahana Likuid Syariah (BLS), the only company's sharia money market fund product.

The results of the stock screening show that there are 31 stocks that have a better risk-adjusted return presented by Sharpe ratio than the reference index of ISSI during the five years of the research period. Of the 31 stocks, there are 14 stocks that are always in the portfolio of Bahana Icon Syariah with a percentage of more than $80 \%$ of the research period, including ASII, BRIS, CTRA, ICBP, INDF, INTP, KLBF, LSIP, PTBA, PWON, SMGR, TLKM, UNTR, and UNVR. The optimal portfolio construction in this condition consists of 31 sharia stocks and BLS.

Historically, Bahana Icon Syariah manages 27 - 30 stocks in a sideways period. As shown in Appendix $\mathrm{B}$, there are 25 stocks that have a higher Sharpe ratio than the reference index and only 14 stocks have a positive Sharpe ratio. Ideally, a company only has to choose stocks that have a positive Sharpe ratio. However, in practical terms, the company manages a minimum of 27 stocks in the sideways period. Therefore, the portfolio construction consists of 27 sharia stocks and BLS. In a bullish condition, Bahana Icon Syariah manages $27-31$ sharia stocks. There are 42 stocks that have a positive Sharpe ratio as seen in Appendix C, but only 7 stocks that have a better Sharpe ratio than the benchmark index. In this analysis, 31 stocks included in the ideal portfolio construction.

In the last five years, Bahana Icon Syariah has managed 26 - 32 stocks in a bearish situation. Appendix D reveals that there are 34 stocks that have better performance in terms of Sharpe ratio than the benchmark index, but only two stocks have a positive Sharpe ratio, namely KAEF and HRUM. On this occasion, 26 sharia stocks are used to form the most optimal portfolio in bearish conditions.

\subsection{Active and Semi-active Investment Strategy}

Generally, Bahana Icon Syariah is classified as a sharia mutual fund that carries an active investment 
strategy. Investment managers will apply various ways to obtain returns that exceed market returns. The objective of an active strategy is to achieve a stock portfolio return that exceeds the stock portfolio return obtained through a passive strategy. After conducting interview with equity analyst, in fact, Bahana Icon Syariah implemented a semi-active strategy which is a combination of active and passive strategy. This strategy involves an enhanced index approach which designed for investors who want to outperform their benchmarks while carefully managing their portfolio's risk exposure. The table 4.1 shows the weighting targets for the active investment strategy:

Table 4.1 The weighting targets for active investment strategy

\begin{tabular}{cccccc}
\hline \multirow{2}{*}{ Condition } & \multicolumn{2}{c}{ Historical (\%) } & \multicolumn{2}{c}{ Target (\%) } \\
\cline { 2 - 6 } & & Min & Max & Min & Max \\
\hline \multirow{4}{*}{ Stocks } & Overall & 0.45 & 14.28 & 0.5 & 15 \\
\cline { 2 - 6 } & Sideways & 0.45 & 13.31 & 0.5 & 15 \\
\cline { 2 - 6 } & Bullish & 0.48 & 14.28 & 0.5 & 15 \\
\cline { 2 - 6 } & Bearish & 0.51 & 10.34 & 0.5 & 15 \\
\cline { 2 - 6 } BLS & Sideways & 8.87 & 14.72 & 0 & 15 \\
\cline { 2 - 6 } & Bullish & 7.46 & 15.02 & 0 & 15 \\
\cline { 2 - 6 } & Bearish & 16.99 & 18.41 & 0 & 20 \\
\cline { 2 - 6 } & & & & &
\end{tabular}

The weighting target in the table 4.1 is also a general target for the semi-active investment strategy, but there are some additional weighting targets for the top 10 stocks with the largest market cap in the Indonesia Sharia Stock Index as of 31 December 2019 which are reflected in the Table 4.2.

Table 4.2 Additional weighting targets for semi-active investment strategy

\begin{tabular}{cccc}
\hline \multirow{2}{*}{$\begin{array}{c}\text { Top 10 Market } \\
\text { Cap in ISSI }\end{array}$} & $\begin{array}{c}\text { Normal } \\
\text { Weight (\%) }\end{array}$ & $\begin{array}{c}\text { Min } \\
\mathbf{( 8 0 \% \text { Normal } )}\end{array}$ & $\begin{array}{c}\text { Max } \\
(\mathbf{1 2 0} \% \text { Normal) }\end{array}$ \\
\cline { 3 - 4 } & 10.50 & 8.40 & 12.60 \\
\hline TLKM & 8.56 & 6.84 & 10.27 \\
\hline UNVR & 7.48 & 5.99 & 8.98 \\
\hline ASII & 4.94 & 3.95 & 5.93 \\
\hline TPIA & 3.59 & 2.87 & 4.31 \\
\hline BRPT & 3.47 & 2.78 & 4.17 \\
\hline ICBP & 2.85 & 2.28 & 3.41 \\
\hline CPIN & 2.14 & 1.71 & 2.57 \\
\hline UNTR & 2.03 & 1.62 & 2.43 \\
\hline KLBF & 1.90 & 1.52 & 2.28 \\
\hline SMGR & & &
\end{tabular}

Both active and semi-active investment strategy uses the mean-variance analysis approach, covariance and correlation analysis, and Sharpe ratio as indicators that can be compared with the performance of the reference index. The difference is that the semi-active strategy always includes risk-adjusted return data for the top 10 constituents in the ISSI which are always listed on JII 30 and JII 70 even though during the period of research their performance was below the reference index and / or had a negative value. 


\subsection{Portfolio Optimization Construction}

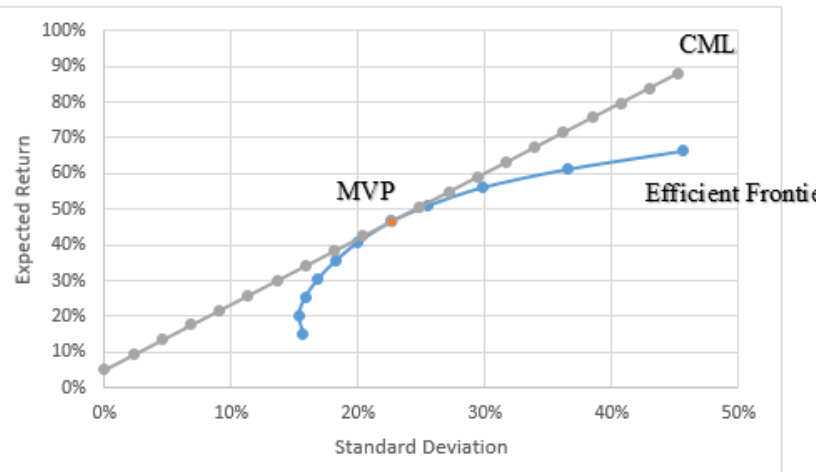

Overall with active investment strategy

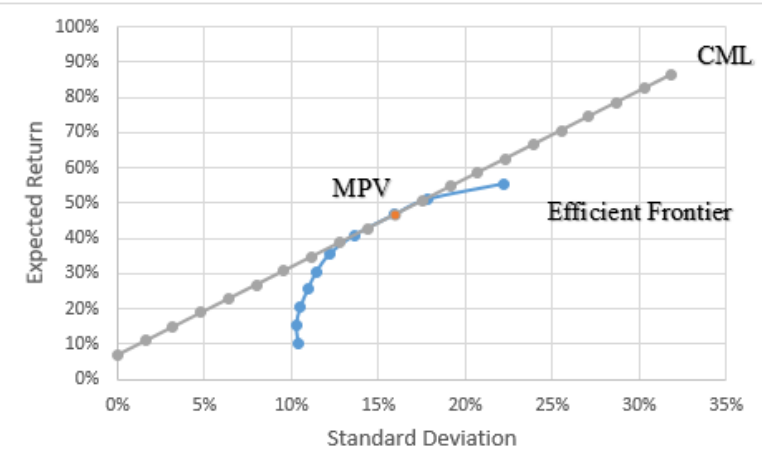

Sideways with active investment strategy

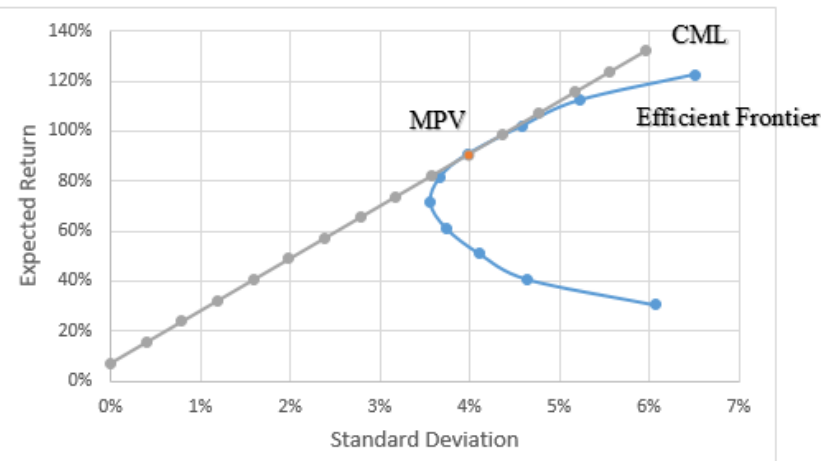

Bullish with active investment strategy

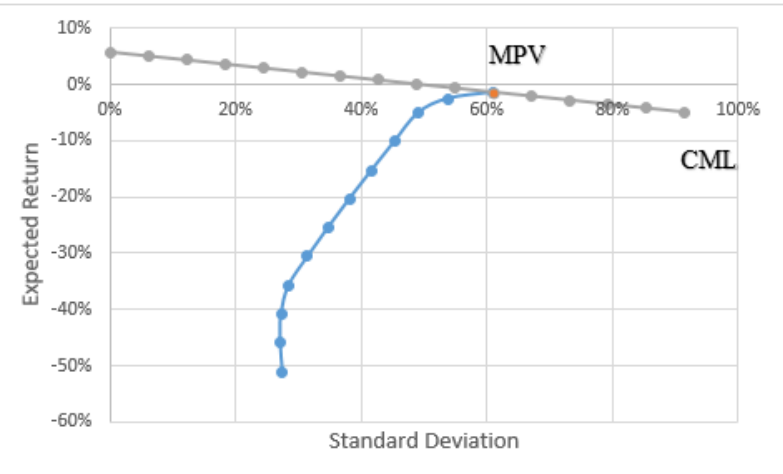

Bearish with active investment strategy

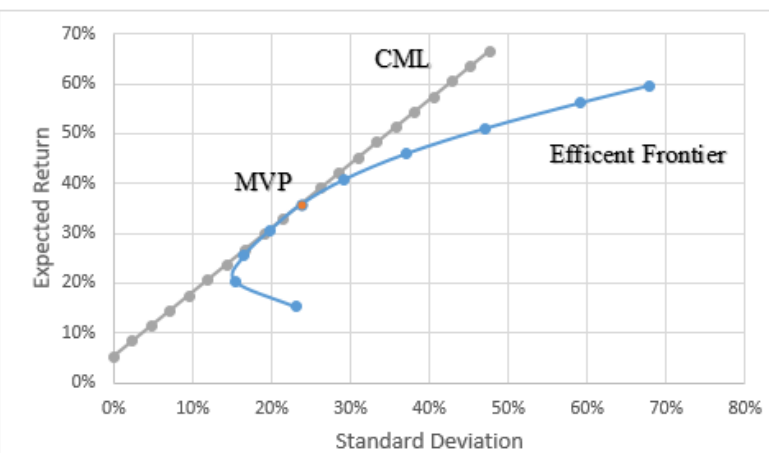

Overall with semi-active investment strategy

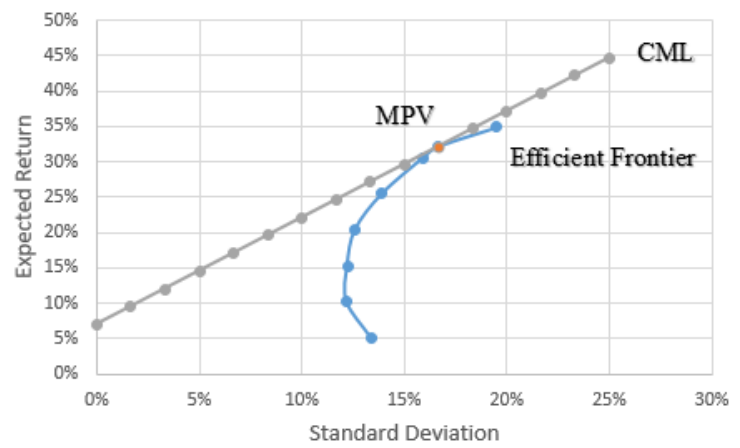

Sideways with semi-active investment strategy

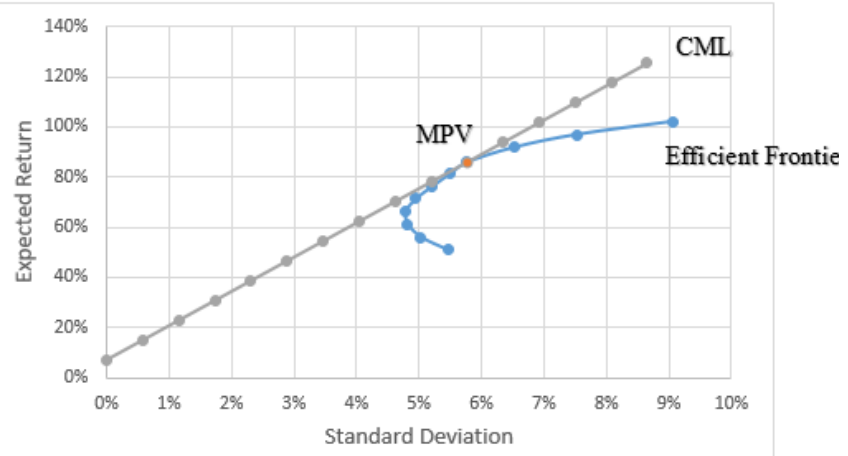

Bullish with semi-active investment strategy

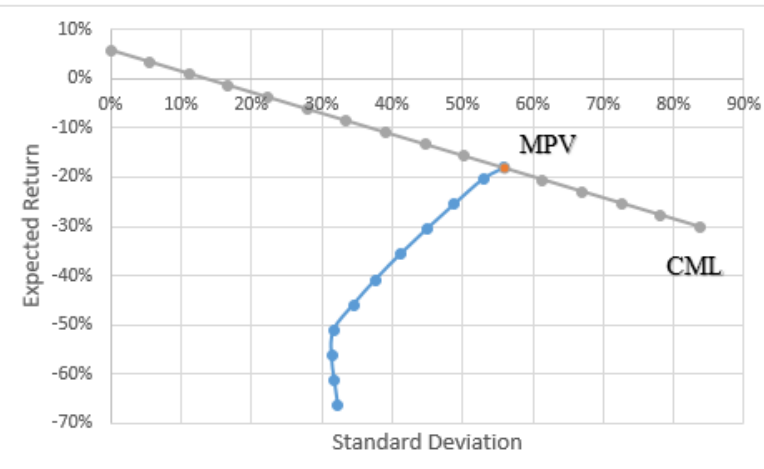

Bearish with semi-active investment strategy

Figure 4.1 Portfolio optimization construction

The MVP is not the predominant point to be used by investment managers, but the MVP will be the minimum point of reference that investment managers can select and consider. The investment manager 
may select all points in the efficient frontier area according to the targets and objectives of the investors. However, what needs to be considered is that the higher the expected return, the higher the risk (standard deviation) that follows. The results of optimal portfolio construction using Markowitz's Modern Portfolio Theory are summarized in Table 4.3.

Table 4.3 Summary of portfolio optimization construction

\begin{tabular}{|c|c|c|c|c|c|c|c|}
\hline \multirow{2}{*}{\multicolumn{2}{|c|}{ Market Conditions }} & \multicolumn{2}{|c|}{ Expected Return } & \multicolumn{2}{|c|}{ Standard Deviation } & \multirow{3}{*}{$\begin{array}{c}\begin{array}{c}\text { Risk-free } \\
\text { (1Y BI Rate) }\end{array} \\
5.25 \%\end{array}$} & \multirow{3}{*}{$\begin{array}{c}\begin{array}{c}\text { Sharpe } \\
\text { Ratio }\end{array} \\
1.83\end{array}$} \\
\hline & & Weekly & Yearly & Weekly & Yearly & & \\
\hline \multirow{3}{*}{$\begin{array}{c}\text { Overall } \\
\text { (Oct'15-Oct'20) }\end{array}$} & Active & $0.91 \%$ & $46.60 \%$ & $3.17 \%$ & $22.60 \%$ & & \\
\hline & Semi-Active & $0.70 \%$ & $35.90 \%$ & $3.34 \%$ & $23.80 \%$ & $5.25 \%$ & 1.29 \\
\hline & ISSI & $0.07 \%$ & $3.49 \%$ & $2.21 \%$ & $15.76 \%$ & $5.25 \%$ & -0.11 \\
\hline \multirow{3}{*}{$\begin{array}{c}\text { Sideways } \\
\text { (May'18-Oct '18) }\end{array}$} & Active & $0.92 \%$ & $46.80 \%$ & $2.23 \%$ & $15.90 \%$ & $7.00 \%$ & 2.49 \\
\hline & Semi-Active & $0.63 \%$ & $32.10 \%$ & $2.33 \%$ & $16.70 \%$ & $7.00 \%$ & 1.51 \\
\hline & ISSI & $-0.03 \%$ & $-0.47 \%$ & $2.29 \%$ & $16.32 \%$ & $7.00 \%$ & -0.46 \\
\hline \multirow{3}{*}{$\begin{array}{c}\text { Bullish } \\
\text { (Oct '18 - Feb '19) }\end{array}$} & Active & $1.78 \%$ & $90.50 \%$ & $0.56 \%$ & $4.00 \%$ & $7.25 \%$ & 20.95 \\
\hline & Semi-Active & $1.69 \%$ & $86.00 \%$ & $0.81 \%$ & $5.80 \%$ & $7.25 \%$ & 13.64 \\
\hline & ISSI & $0.61 \%$ & $31.07 \%$ & $1.10 \%$ & $7.88 \%$ & $7.25 \%$ & 3.02 \\
\hline \multirow{3}{*}{$\begin{array}{c}\text { Bearish } \\
\text { (Dec'19-Mar'20) }\end{array}$} & Active & $-0.03 \%$ & $-1.40 \%$ & $8.53 \%$ & $60.90 \%$ & $5.75 \%$ & -0.12 \\
\hline & Semi-Active & $-0.36 \%$ & $-18.10 \%$ & $7.82 \%$ & $55.80 \%$ & $5.75 \%$ & -0.43 \\
\hline & ISSI & $-2.14 \%$ & $-105.01 \%$ & $5.28 \%$ & $37.72 \%$ & $5.75 \%$ & -3.05 \\
\hline
\end{tabular}

Table 4.3 provides a summary of the top 10 stocks in the optimal portfolio construction with a stock weight of more than the minimum weighting of 0.5 percent:

Table 4.3 The top 10 stocks in the optimal weight-based portfolio

\begin{tabular}{ccl}
\hline \multirow{2}{*}{ Overall } & Active & BRPT, TPIA, BTPS, ACES, HRUM, PTBA, CPIN, JPFA, BRIS, MAPI \\
\cline { 2 - 3 } & Semi-Active & ACES, BTPS, HRUM, TLKM, UNVR, ASII, PTBA, TPIA, BRPT, ICBP \\
\hline \multirow{2}{*}{ Sideways } & Active & BTPS, CPIN, TLKM, LSIP, KAEF, ICBP, JPFA, PTBA \\
\cline { 2 - 3 } & Semi-Active & BTPS, JPFA, LSIP, TLKM, PTBA, KAEF, UNVR, ASII, TPIA, CPIN \\
\hline \multirow{2}{*}{ Bullish } & Active & BRPT, WTON, AKRA, RALS, TLKM, ICBP, INCO, MIKA, TPIA, CPIN \\
\cline { 2 - 3 } Bearish & Semi-Active & AKRA, WTON, MIKA, RALS, TLKM, UNVR, ASII, TPIA, BRPT, EXCL \\
\cline { 2 - 3 } & Active & HRUM, ICBP, INDF, KAEF, BRPT \\
\hline \multirow{2}{*}{ Semi-Active } & HRUM, KAEF, TLKM, UNVR, ASII, ICBP, INDF, TPIA, EXCL \\
\hline
\end{tabular}

\subsubsection{Overall Condition Overview}

BRPT, TPIA, BTPS, ACES, and HRUM are always in two optimal portfolios on two different strategies. The five stocks are also not the 14 stocks that are always in the Bahana Icon Syariah portfolio with a percentage of more than $80 \%$ during the observation period. On the other hand, the stocks of BTPS, ACES, HRUM, PTBA, CPIN, JPFA, BRIS, and MAPI are eight stocks outside of ISSI's top 10 market cap, but their performance is able to be present in the top 10 stock allocations in the active investment strategy.

\subsubsection{Sideways Condition Overview}

In this condition, BTPS, TLKM, LSIP, KAEF, JPFA, and PTBA always exist in both investment strategies. Only BTPS, JPFA, and KAEF are not the 14 stocks that always exist in the Bahana Icon Syariah portfolio with a percentage of more than $80 \%$ during the observation period.

\subsubsection{Bullish Condition Overview}

In the bullish condition, almost all stocks during the observation period performed well. BRPT, WTON, AKRA, RALS, and TLKM shares are always in the top 10 share allocations in two different investment strategies. Only TLKM is always in the Bahana Icon Syariah portfolio during the research period with a percentage of $100 \%$. 


\subsubsection{Bearish Condition Overview}

In this condition, almost all stocks experienced a significant contraction, only two stocks posted positive performance, namely KAEF and HRUM.

\section{Conclusion and Recommendations}

There are two things that can be concluded in this study:

1. The concept of Markowitz's Modern Portfolio Theory can be applied to any type of market conditions because it always generates higher expected return and Sharpe ratio than the reference index.

2. In any type of market conditions, the active investment strategy is always superior to the semi-active investment strategy based on the Sharpe ratio.

The output of this research is to provide recommendations to investment managers using Markowitz's Modern Portfolio Theory. Recommendations are based on three criteria, in (stocks that are worthy of being included in the portfolio), watch list (stocks that are worth considering), and out (stocks that are worthy of being removed from the portfolio). In based on only top 10 stocks in overall condition, watch list based on top 10 stocks that are always listed in two strategies in bullish, sideways, and/or bearish conditions, and out based on the stocks that are not included in the 31 stock screening results in the overall condition.

\begin{tabular}{ll}
\hline In & BRPT, TPIA, BTPS, ACES, HRUM, CPIN, JPFA, MAPI \\
\hline Watch list & AKRA, KAEF, RALS, WTON \\
\hline Out & ADHI, ASRI, BSDE, IPCC, INTP, MIKA, PTPP, WIKA, WSBP \\
\hline
\end{tabular}

The recommendations above are only based on the results of research using the Modern Portfolio Theory concept in a specific time frame. Furthermore, investment managers are required to review these stocks using fundamental and technical approaches before deciding on an investment policy.

\section{References}

Al-Abedallat, A. Z., \& Al Shabib, D. K. (2012). Impact of the Investment and Gross Domestic Product (GDP) on the Amman Stock Exchange Index. Investment Management and Financial Innovations, 9(3), 130-136.

Chen, W. P., Chung, H., Ho, K. Y., \& Hsu, T. L. (2010). Portfolio Optimization Models and MeanVariance Spanning Tests. In C. F. Lee, A. C. Lee, \& J. C. Lee, Handbook of Quantitative Finance and Risk Management (pp. 165-184). New York: Springer Science+Business Media.

Dimson, E., Marsh, P., \& Staunton, M. (2012). Credit Suisse Global Investment Returns Sourcebook 2012. Zurich: Credit Suisse Research Institute.

Indonesia Central Securities Depository. (2020, September). Peran Strategis KSEI dalam Meningkatkan Stabilitas Pasar Modal. KSEI News, pp. 1-11.

International Monetary Fund. (2020). World Economic Outlook: A Long and Difficult Ascent. Washington DC: International Monetary Fund Publication Services.

Ivanova, M., \& Dospatliev, L. (2017). Application of Markowitz Portfolio Optimization on Bulgarian Stock Market from 2013 to 2016. International Journal of Pure and Applied Mathematics, 117(2), 291-307.

Lee, C. F., Finnerty, J. E., \& Chen, H. Y. (2010). Risk-Aversion, Capital Asset Allocation, and Markowitz Portfolio-Selection Model. In C. F. Lee, A. C. Lee, \& J. C. Lee, Handbook of Quantitative Finance and Risk Management (pp. 69-92). New York: Springer Science+Business Media.

Markowitz, H. M. (1952). Portfolio Selection. The Journal of Finance, 7, 77-91.

Markowitz, H. M. (1959). Portfolio Selection: Efficient Diversificaiton of Investments. New York: John Wiley \& Sons, Inc.

Park, S. (1997). Rationality of Negative Stock-Price Responses to Strong Economic Activity. Financial Analysts Journal, 52-56. 
PT Bahana TCW Investment Management. (2020). Pembaharuan Prospektus Reksa Dana Bahana Icon Syariah. Jakarta: PT Bahana TCW Investment Management.

Ritter, J. R. (2012). Is Economic Growth Good for Investors? Journal of Applied Corporate Finance, 24(3), 8-18.

Setiawan, S. A. (2020). Does Macroeconomic Condition Matter for Stock Market? Evidence of Indonesia Stock Market Performance for 21 Years. The Indonesian Journal of Development Planning, 4(1), 27-39.

Sharpe, W. F. (1966). Mutual Fund Performance. Journal of Business, 39, 119-138.

Vo, D. H., Pham, T. N., Pham, T. T., Truong, L. M., \& Nguyen, T. C. (2019). Risk, Return and Portfolio Optimization for Various Industries in the ASEAN Region. Borsa Istanbul Review, 19(2), 132-138.

Yuana, I., Topowijono, \& Azizah, D. F. (2016). Analisis Pembentukan Portofolio Saham Optimal dengan Model Markowitz sebagai Dasar Penetapan Investasi. Jurnal Administrasi Bisnis, 39(1), 90-98. 


\section{Appendix A}

Overall stock screening result

\begin{tabular}{|c|c|c|c|c|c|c|c|}
\hline No. & $\begin{array}{l}\text { Stock's } \\
\text { Code }\end{array}$ & Company's Name & $\begin{array}{c}\text { Sharpe } \\
\text { Ratio }\end{array}$ & No. & $\begin{array}{l}\text { Stock's } \\
\text { Code }\end{array}$ & Company's Name & $\begin{array}{c}\text { Sharpe } \\
\text { Ratio }\end{array}$ \\
\hline 1 & BRPT & PT Barito Pacific Tbk & 1.38 & 18. & ITMG & PT Indo Tambangraya Megah Tbk & 0.28 \\
\hline 2. & TPIA & PT Chandra Asri Petrochemical Tbk & 1.38 & 19. & INDF & PT Indofood Sukses Makmur Tbk & 0.27 \\
\hline 3. & BTPS & PT Bank BTPS Syariah Tbk & 0.8 & 20. & UNTR & PT United Tractors Tbk & 0.26 \\
\hline 4. & JPFA & PT Japfa Comfeed Indonesia Tbk & 0.68 & 21. & RALS & PT Ramayana Lestari Sentosa Tbk & 0.23 \\
\hline 5. & ACES & PT Ace Hardware Indonesia Tbk & 0.66 & 22. & PWON & PT Pakuwon Jati Tbk & 0.19 \\
\hline 6. & KAEF & PT Kimia Farma Tbk & 0.65 & 23. & CTRA & PT Ciputra Development Tbk & 0.17 \\
\hline 7. & PTBA & PT Bukit Asam Tbk & 0.65 & 24. & SMGR & PT Semen Indonesia Tbk & 0.14 \\
\hline 8. & BRIS & PT Bank BRIsyariah Tbk & 0.62 & 25. & ASII & PT Astra International Tbk & 0.13 \\
\hline 9. & CPIN & PT Charoen Pokphand Indonesia Tbk & 0.58 & 26. & KLBF & PT Kalbe Farma Tbk & 0.12 \\
\hline 10. & ADRO & PT Adaro Energy Tbk & 0.56 & 27. & UNVR & PT Unilever Indonesia Tbk & 0.11 \\
\hline 11. & HRUM & PT Harum Energy Tbk & 0.55 & 28. & EXCL & PT XI Axiata Tbk & 0.04 \\
\hline 12. & ANTM & PT Aneka Tambang Tbk & 0.52 & 29. & INTP & PT Indocement Tunggal Prakarsa Tbk & 0.01 \\
\hline 13. & DMAS & PT Puradelta Lestari Tbk & 0.44 & 30. & LSIP & PT PP London Sumatra Indonesia Tbk & 0.01 \\
\hline 14. & MAPI & PT Mitra Adiperkasa Tbk & 0.44 & 31. & TLKM & PT Telekomunikasi Indonesia Tbk & 0.01 \\
\hline 15. & SMBR & PT Semen Baturaja Tbk & 0.41 & - & ISSI & Indonesia Sharia Stock Index & -0.11 \\
\hline 16. & ICBP & PT Indofood CBP Sukses Makmur Tbk & 0.38 & - & BLS & Bahana Likuid Syariah & 1.62 \\
\hline 17. & INCO & PT Vale Indonesia Tbk & 0.34 & & & & \\
\hline
\end{tabular}

\section{Appendix B}

Sideways stock screening result

\begin{tabular}{|c|c|c|c|c|c|c|c|}
\hline No. & $\begin{array}{c}\text { Stock's } \\
\text { Code }\end{array}$ & Company's Name & $\begin{array}{c}\text { Sharpe } \\
\text { Ratio }\end{array}$ & No. & $\begin{array}{c}\text { Stock's } \\
\text { Code }\end{array}$ & Company's Name & $\begin{array}{c}\text { Sharpe } \\
\text { Ratio }\end{array}$ \\
\hline 1 & CPIN & PT Charoen Pokphand Indonesia Tbk & 2.56 & 17. & PWON & PT Pakuwon Jati Tbk & -0.13 \\
\hline 2. & BTPS & PT Bank BTPS Syariah Tbk & 1.55 & 18. & KLBF & PT Kalbe Farma Tbk & -0.23 \\
\hline 3. & JPFA & PT Japfa Comfeed Indonesia Tbk & 1.49 & 19. & MAPI & PT Mitra Adiperkasa Tbk & -0.25 \\
\hline 4. & PTBA & PT Bukit Asam Tbk & 1.06 & 20. & INDF & PT Indofood Sukses Makmur Tbk & -0.29 \\
\hline 5. & ASII & PT Astra International Tbk & 0.94 & 21. & ADRO & PT Adaro Energy Tbk & -0.47 \\
\hline 6. & KAEF & PT Kimia Farma Tbk & 0.91 & 22. & CTRA & PT Ciputra Development Tbk & -0.48 \\
\hline 7. & LSIP & PT PP London Sumatra Indonesia Tbk & 0.83 & 23. & BRIS & PT Bank BRIsyariah Tbk & -0.50 \\
\hline 8. & ICBP & PT Indofood CBP Sukses Makmur Tbk & 0.77 & 24. & AALI & PT Astra Agro Lestari Tbk & -0.52 \\
\hline 9. & ACES & PT Ace Hardware Indonesia Tbk & 0.69 & 25 . & HRUM & PT Harum Energy Tbk & -0.54 \\
\hline 10. & TLKM & PT Telekomunikasi Indonesia Tbk & 0.56 & 26. & UNTR & PT United Tractors Tbk & -0.57 \\
\hline 11. & EXCL & PT XL Axiata Tbk & 0.41 & 27. & BRPT & PT Barito Pacific Tbk & -1.01 \\
\hline 12. & SMGR & PT Semen Indonesia Tbk & 0.40 & 28 & UNVR & PT Unilever Indonesia Tbk & -1.28 \\
\hline 13. & PGAS & PT Perusahaan Gas Negara Tbk & 0.29 & 29. & TPIA & PT Chandra Asri Petrochemical Tbk & -1.65 \\
\hline 14. & INCO & PT Vale Indonesia Tbk & 0.15 & - & ISSI & Indonesia Sharia Stock Index & -0.57 \\
\hline 15. & INTP & PT Indocement Tunggal Prakarsa Tbk & -0.08 & - & BLS & Bahana Likuid Syariah & -9.10 \\
\hline 16. & ITMG & PT Indo Tambangraya Megah Tbk & -0.09 & & & & \\
\hline
\end{tabular}




\section{Appendix C}

Bullish stock screening result

\begin{tabular}{|c|c|c|c|c|c|c|c|}
\hline No. & $\begin{array}{l}\text { Stock's } \\
\text { Code }\end{array}$ & Company's Name & $\begin{array}{c}\text { Sharpe } \\
\text { Ratio }\end{array}$ & No. & $\begin{array}{l}\text { Stock's } \\
\text { Code }\end{array}$ & Company's Name & $\begin{array}{c}\text { Sharpe } \\
\text { Ratio }\end{array}$ \\
\hline 1 & BRPT & PT Barito Pacific Tbk & 5.41 & 24. & KAEF & PT Kimia Farma Tbk & 1.51 \\
\hline 2. & DMAS & PT Puradelta Lestari Tbk & 3.73 & 25. & KLBF & PT Kalbe Farma Tbk & 1.33 \\
\hline 3. & AKRA & PT AKR Corporindo Tbk & 3.56 & 26. & UNVR & PT Unilever Indonesia Tbk & 1.31 \\
\hline 4. & WIKA & PT Wijaya Karya Tbk & 3.42 & 27. & WSBP & PT Waskita Beton Precast Tbk & 1.29 \\
\hline 5. & WTON & PT Wijaya Karya Beton Tbk & 3.22 & 28. & SCMA & PT Surya Citra Media Tbk & 1.29 \\
\hline 6. & SMGR & PT Semen Indonesia Tbk & 3.08 & 29. & BMTR & PT Global Mediacom Tbk & 1.25 \\
\hline 7. & INDF & PT Indofood Sukses Makmur Tbk & 3.02 & 30. & PGAS & PT Perusahaan Gas Negara Tbk & 1.20 \\
\hline 8. & RALS & PT Ramayana Lestari Sentosa Tbk & 2.81 & 31. & ASRI & PT Alam Sutera Realty Tbk & 1.16 \\
\hline 9. & ACES & PT Ace Hardware Indonesia Tbk & 2.76 & 32. & INTP & PT Indocement Tunggal Prakarsa Tbk & 1.11 \\
\hline 10. & ANTM & PT Aneka Tambang Tbk & 2.46 & 33. & MNCN & PT Media Nusantara Citra Tb & 1.02 \\
\hline 11. & SMRA & PT Summarecon Agung Tbk & 2.41 & 34. & CTRA & PT Ciputra Development Tbk & 1.01 \\
\hline 12. & APLN & PT Agung Podomoro Land Tbk & 2.41 & 35. & LPPF & PT Matahari Department Store Tbk & 0.88 \\
\hline 13. & MIKA & PT Mitra Keluarga Karyasehat Tbk & 2.23 & 36. & TLKM & PT Telekomunikasi Indonesia Tbk & 0.70 \\
\hline 14. & ADHI & PT Adhi Karya Tbk & 2.12 & 37. & JPFA & PT Japfa Comfeed Indonesia Tbk & 0.63 \\
\hline 15. & MAPI & PT Mitra Adiperkasa Tbk & 2.11 & 38. & LPKR & PT Lippo Karawaci Tbk & 0.55 \\
\hline 16. & BTPS & PT Bank BTPS Syariah Tbk & 2.07 & 39. & AALI & PT Astra Agro Lestari Tbk & 0.49 \\
\hline 17. & PTPP & PT Pembangunan Perumahan Tbk & 2.07 & 40 . & BRIS & PT Bank BRIsyariah Tbk & 0.14 \\
\hline 18. & PWON & PT Pakuwon Jati Tbk & 2.06 & 41. & LINK & PT Link Net Tbk & 0.10 \\
\hline 19. & TPIA & PT Chandra Asri Petrochemical Tbk & 2.05 & 42. & LSIP & PT PP London Sumatra Indonesia Tbk & 0.06 \\
\hline 20. & INCO & PT Vale Indonesia Tbk & 1.96 & 43. & ASII & PT Astra International Tbk & -0.43 \\
\hline 21. & CPIN & PT Charoen Pokphand Indonesia Tbk & 1.80 & 44. & UNTR & PT United Tractors Tbk & -1.56 \\
\hline 22. & ICBP & PT Indofood CBP Sukses Makmur Tbk & 1.74 & - & ISSI & Indonesia Sharia Stock Index & 3.02 \\
\hline 23. & BSDE & PT Bumi Serpong Damai Tbk & 1.53 & - & BLS & Bahana Likuid Syariah & -14.47 \\
\hline
\end{tabular}

\section{Appendix D}

Bearish stock screening result

\begin{tabular}{|c|c|c|c|c|c|c|c|}
\hline No. & $\begin{array}{l}\text { Stock's } \\
\text { Code }\end{array}$ & Company's Name & $\begin{array}{c}\text { Sharpe } \\
\text { Ratio }\end{array}$ & No. & $\begin{array}{c}\text { Stock's } \\
\text { Code }\end{array}$ & Company's Name & $\begin{array}{c}\text { Sharpe } \\
\text { Ratio }\end{array}$ \\
\hline 1 & KAEF & PT Kimia Farma Tbk & 0.74 & 20. & UNTR & PT United Tractors Tbk & -1.98 \\
\hline 2. & HRUM & PT Harum Energy Tbk & 0.32 & 21. & ANTM & PT Aneka Tambang Tbk & -2.16 \\
\hline 3. & BRPT & PT Barito Pacific Tbk & -0.41 & 22. & TPIA & PT Chandra Asri Petrochemical Tbk & -2.16 \\
\hline 4. & ADRO & PT Adaro Energy Tbk & -0.74 & 23. & APLN & PT Agung Podomoro Land Tbk & -2.25 \\
\hline 5. & ICBP & PT Indofood CBP Sukses Makmur Tbk & -0.75 & 24. & SMGR & PT Semen Indonesia Tbk & -2.28 \\
\hline 6. & INCO & PT Vale Indonesia Tbk & -1.02 & 25 . & PWON & PT Pakuwon Jati Tbk & -2.29 \\
\hline 7. & INDF & PT Indofood Sukses Makmur Tbk & -1.09 & 26. & WTON & PT Wijaya Karya Beton Tbk & -2.40 \\
\hline 8. & ACES & PT Ace Hardware Indonesia Tbk & -1.09 & 27. & ADHI & PT Adhi Karya Tbk & -2.41 \\
\hline 9. & PTBA & PT Bukit Asam Tbk & -1.19 & 28. & SMBR & PT Semen Baturaja Tbk & -2.50 \\
\hline 10. & ITMG & PT Indo Tambangraya Megah Tbk & -1.22 & 29. & LPKR & PT Lippo Karawaci Tbk & -2.57 \\
\hline 11. & LSIP & PT PP London Sumatra Indonesia Tbk & -1.29 & 30. & INTP & PT Indocement Tunggal Prakarsa Tbk & -2.57 \\
\hline 12. & KLBF & PT Kalbe Farma Tbk & -1.29 & 31. & BMTR & PT Global Mediacom Tbk & -2.62 \\
\hline 13. & MIKA & PT Mitra Keluarga Karyasehat Tbk & -1.39 & 32. & AKRA & PT AKR Corporindo Tbk & -2.65 \\
\hline 14. & UNVR & PT Unilever Indonesia Tbk & -1.48 & 33. & WIKA & PT Wijaya Karya Tbk & -2.84 \\
\hline 15. & BRIS & PT Bank BRIsyariah Tbk & -1.56 & 34. & MNCN & PT Media Nusantara Citra Tb & -2.90 \\
\hline 16. & CPIN & PT Charoen Pokphand Indonesia Tbk & -1.59 & 35 . & ASII & PT Astra International Tbk & -3.05 \\
\hline 17. & JPFA & PT Japfa Comfeed Indonesia Tbk & -1.67 & 36. & ISSI & Indonesia Sharia Stock Index & -3.47 \\
\hline 18. & EXCL & PT XL Axiata Tbk & -1.78 & 37. & BLS & Bahana Likuid Syariah & -12.78 \\
\hline 19. & TLKM & PT Telekomunikasi Indonesia Tbk & 1.82 & & & & \\
\hline
\end{tabular}

